\title{
Supplementation of fresh ucche (Momordica charantia L. var. muricata Willd) prevented oxidative stress, fibrosis and hepatic damage in $\mathrm{CCl}_{4}$ treated rats
}

\author{
Abu Taher Sagor ${ }^{1 \dagger}$, Mohammed Riaz Hasan Chowdhury ${ }^{1 \dagger}$, Nabila Tabassum¹, Hemayet Hossain², \\ Md Mahbubur Rahman ${ }^{1}$ and Md Ashraful Alam ${ }^{1 *}$
}

\begin{abstract}
Background: Ucche (Momordica charantia L. var. muricata (Willd.) Chakravarty) has been reported to possess many benefits and medicinal properties. However, the protective effect of ucche against carbon tetrachloride $\left(\mathrm{CCl}_{4}\right)$ induced hepatotoxicity have not been clarified fully yet. The aim of the present study was to investigate the effects of ucche on oxidative stress and inflammation in liver of $\mathrm{CCl}_{4}$ treated rats.

Methods: Female Long Evans rats were administered with $\mathrm{CCl}_{4}$ orally $(1 \mathrm{ml} / \mathrm{kg})$ twice a week for 2 weeks and were supplemented with freshly prepared crashed ucche (10\% wt/wt of diet) with powdered chaw food. Both plasma and liver tissues were analyzed for AST, ALT and ALP activities. Oxidative stress parameters were measure by determining malondialdehyde (MDA), nitric oxide (NO), advanced protein oxidation product (APOP), and reduced glutathione (GSH) concentrations and catalase activities in plasma and liver tissues. Moreover, inflammation and tissue fibrosis were confirmed by histological staining of liver tissue sections.

Results: Our data suggest that ucche significantly prevented $\mathrm{CCl}_{4}$-induced hepatotoxicity, indicated by both diagnostic indicators of liver damage (serum transferases activities) and histopathological analysis. Moreover, $\mathrm{CCl}_{4}$ administration induced profound elevation of reactive oxygen species (ROS) production and oxidative stress, as evidenced by increasing lipid peroxidation level and depletion of antioxidant enzymes in liver. Fresh ucche supplementation prevented the oxidative stresses and improved antioxidant enzyme function. Furthermore, fresh ucche supplementation reduced hepatic inflammatory cell infiltration, iron deposition and fibrosis in liver of $\mathrm{CCl}_{4}$ treated rats.
\end{abstract}

Conclusion: In conclusion, these results suggested that the inhibition of $\mathrm{CCl}_{4}$-induced inflammation by ucche is due at least in part to its anti-oxidant activity and its ability to modulate the inflammation and fibrosis in liver.

Keywords: Momordica charantia, Fibrosis, Inflammation, Reactive oxygen species, Oxidative stress, Aminotransferases

\section{Background}

Liver is the main organ for nutrition metabolism and detoxifying foreign chemical agents in living animals. Other functions of liver are helping digestion, production of invaluable endogenous hormones, enzymes as well as production of glucose while fasting. However, hepatic

\footnotetext{
*Correspondence: sonaliagun@yahoo.com

${ }^{\dagger}$ Equal contributors

'Department of Pharmaceutical Sciences, North South University, Dhaka, Bangladesh

Full list of author information is available at the end of the article
}

dysfunctions like cirrhosis, steatosis, hepatitis as well as drug induced hepatic damages are increasing day by day [1]. Oxidative stress has been proposed to be increased in most cases of liver dysfunction mentioned above. Carbon tetrachloride $\left(\mathrm{CCl}_{4}\right)$ is a well known hepatotoxin used extensively for the study hepatotoxicity in animal models. $\mathrm{CCl}_{4}$ stimulates bio-activation of the phase I cytochrome $\mathrm{P} 450$ system to form reactive metabolic trichloromethyl radicals $\left({ }^{\circ} \mathrm{CCl} 3\right)$ and peroxy trichloromethyl radicals $\left({ }^{\circ} \mathrm{OOCCl}_{3}\right)$ [2]. These peroxy radicals stimulate kupffer cells to produce $\mathrm{ROS}$, such as ${ }^{\circ} \mathrm{O}_{2}^{-}$,

\section{Ciomed Central}

(C) 2015 Sagor et al.; licensee BioMed Central. This is an Open Access article distributed under the terms of the Creative Commons Attribution License (http://creativecommons.org/licenses/by/4.0), which permits unrestricted use, distribution, and reproduction in any medium, provided the original work is properly credited. The Creative Commons Public Domain Dedication waiver (http://creativecommons.org/publicdomain/zero/1.0/) applies to the data made available in this article, unless otherwise stated. 
$\mathrm{H}_{2} \mathrm{O}_{2}$ and ${ }^{\circ} \mathrm{OH}$, which thus causes lipid peroxidation and reported to induce acute and chronic tissue injuries $[3,4]$. Free radicals generated by $\mathrm{CCl}_{4}$ are thus responsible for the membrane disintegration of hepatocytes which subsequently release marker enzymes of hepatotoxicity such as aspartate transaminase (AST), alanine transaminase (ALT), alkaline phosphatase (ALP) and lactate dehydrogenase (LDH) [5]. Centrilobular necrosis and steatosis are also commonly seen in $\mathrm{CCl}_{4}$ - induced liver toxicities $[5,6]$. Inflammation and fibrosis are some other early events which may also occur during the progression of the liver damage due to $\mathrm{CCl}_{4}$ challenge $[7,8]$.

Bitter melon (Momordica charantia) is a culinary bitter vegetable commonly used in traditional dishes in Bangladesh and Indian subcontinent [9]. Bitter melon can be found in different shapes and sizes. Generally, two varieties of bitter melon are found, mainly karela (Momordica charantia L. var. charantia C. B. Clarke) and ucche (Momordica charantia L. var. muricata (Willd.) Chakravarty). Karela is $20-30 \mathrm{~cm}$ long, oblong with bluntly tapering ends and pale green in color, while ucche is only $6-10 \mathrm{~cm}$ in length and has a narrower shape with pointed ends, and a dark green surface covered with jagged, triangular "teeth" and ridges. Both varieties are also used as a traditional medicine for the treatment of diabetes and other stomach complaints in Bangladesh. Recent evidences suggest that Momordica charantia extract may improve insulin resistance [10] and lowers plasma lipid profile in diabetic and obese experimental animals $[11,12]$. Momordica charantia extract also improved antioxidant status and prevents oxidative stress in vivo [13]. Several bioactive molecules were isolated from Momordica charantia leaves, fruits and seeds [14-17]. Gallic acid, tannic acid, (+)-catechin, caffeic acid, $p$-coumaric, gentisic acid, chlorogenic acid, and epicatechin have been isolated from various parts of Momordica charantia plants [18]. Moreover, cucurbitane type triterpenoids such as charantin, kuguacins, momordicin, and karavilagenins were also isolated from Momordica charantia [18]. The extract also showed antioxidant activities in various experimental models [19]. However, karela variety is extensively studied in most scientific research reported to date, whereas ucche variety is less explored for any proper scientific evaluation. Thus, the current study was undertaken to evaluate the therapeutic benefit of ucche in oxidative stress, inflammation, fibrosis and liver damage induced by $\mathrm{CCl}_{4}$ treated rats.

\section{Methods}

\section{Plant material and preparation of extracts}

Momordica charantia fruits were purchased from a local vegetable market in Dhaka, Bangladesh. This plant has been identified by the expert Mr. Sarker Nasir Uddin, Senior Scientific Officer, of National Herberium, Mirpur, Dhaka Bangladesh and a voucher specimen was deposited
(Acc No. 40566) for future reference. Fresh fruits (250 g) were taken and cut into small pieces and macerated in electrical blander without adding any water. This suspension was used as a supplementation to add with powder food (10\% W/W of diet).

\section{Animals and treatment}

Ten to twelve weeks old, 24 Long Evans female rats (150-210 g) were obtained from Animal production unit of Animal House at Department of Pharmaceutical Sciences, North South University and were kept in individual cages at room temperature of $25 \pm 3^{\circ} \mathrm{C}$ with a $12 \mathrm{~h}$ dark/light cycles. They have free access to standard laboratory feed (Pellet food was crushed to powder) and water, according to the study protocol approved by Ethical Committee of Department of Pharmaceutical Sciences, North South University for animal care and experimentation. To study the hepatoprotective effects of Ucche, rats were equally divided into four groups (six rats each): Group I (Control), Group II (Control + Ucche), Group III $\left(\mathrm{CCl}_{4}\right)$ and Group IV $\left(\mathrm{CCl}_{4}+\right.$ Ucche). Animals of group I and II were treated with $1 \mathrm{ml} / \mathrm{kg}$ of saline $(0.85 \%)$ and olive oil $(1 \mathrm{ml} / \mathrm{kg})$ intragastrically twice a week for two weeks. Rats of group II were supplanted with Ucche fruit in powder food (10\% of powder food, w/w). Rats of group III and IV were treated with $\mathrm{CCl}_{4}$ (1:3 in olive oil) at a dose of $1 \mathrm{ml} / \mathrm{kg}$ intragastrically twice a week for two weeks. Animals of group III received only $\mathrm{CCl}_{4}$ treatment; however, animals of group IV received ucche fruit crashed in powder food (10\% of powder food, w/w) along with $\mathrm{CCl}_{4}$ treatment. Animals were checked for the body weight, food and water intake on a daily basis. After 14 days all animals were weighted, sacrificed, collected the blood and all internal organs such as heart, kidney, spleen and liver. Immediately after collection of the organs, they were weighted and stored in neutral buffered formalin $\left(\mathrm{pH}\right.$ 7.4) for histological analysis and in refrigerator at $-20^{\circ} \mathrm{C}$ for further studies. Collected blood was centrifuged at $8000 \mathrm{rpm}$ and separated the plasma and stored in refrigerator at $-20^{\circ} \mathrm{C}$ for further analysis.

\section{Assessment of hepatotoxicity}

Liver marker enzymes (alanine aminotransferase (ALT), aspartate aminotransferase (AST), and alkaline phosphatase (ALP) were estimated in plasma by using Diatech diagnostic kits (Hungary) according to the manufacturers protocol.

\section{Preparation of tissue sample for the assessment of oxidative stress markers}

For determination of oxidative stress markers, liver tissue was homogenized in 10 volumes of Phosphate buffer containing $(\mathrm{pH} 7.4)$ and centrifuged at $12,000 \times \mathrm{g}$ for $30 \mathrm{~min}$ at $4^{\circ} \mathrm{C}$. The supernatant was collected and used 
for the determination of protein and enzymatic studies as described below.

\section{Estimation of lipid peroxidation}

Lipid peroxidation in liver was estimated colorimetrically measuring malondialdehyde (MDA) followed by previously described method [20]. In brief, $0.1 \mathrm{ml}$ of tissue homogenate (Tris- $\mathrm{HCl}$ buffer, $\mathrm{pH}$ 7.5) was treated with $2 \mathrm{ml}$ of (1:1:1 ratio) TBA-TCA-HCl reagent (thiobarbituric acid $0.37 \%, 0.25 \mathrm{~N} \mathrm{HCl}$ and $15 \%$ TCA) and placed in hot water bath for $15 \mathrm{~min}$ and cooled. The absorbance of clear supernatant was measured against reference blank at $535 \mathrm{~nm}$.

\section{Estimation of nitric oxide (NO)}

Nitric oxide (NO) was determined according to the method described by Tracy et al. as nitrate and nitrite [21]. In this study, Griess-Illosvoy reagent was modified by using naphthyl ethylene diamine dihydrochloride $(0.1 \% \mathrm{w} / \mathrm{v})$ instead of 1-napthylamine $(5 \%)$. The reaction mixture $(3 \mathrm{~mL})$ containing brain homogenates $(2 \mathrm{~mL})$ and phosphate buffer saline $(0.5 \mathrm{~mL})$ was incubated at $25^{\circ} \mathrm{C}$ for $150 \mathrm{~min}$. A pink colored chromophore was formed which was measured at $540 \mathrm{~nm}$ against the corresponding blank solutions with a spectrophotometer. NO level was calculated as nitrate by using Sodium nitrate standard curve and expressed as $\mathrm{nmol} / \mathrm{mL}$.

\section{Estimation of Advanced protein oxidation products (APOP)}

APOP level was performed using previously described method reported by Witko-Sarsat [22] and Tiwari [23]. Two $\mathrm{mL}$ of plasma was diluted (1:5) in PBS, $0.1 \mathrm{~mL}$ potassium iodide $(1.16 \mathrm{M})$ was then added to each tube, followed by $0.2 \mathrm{~mL}$ acetic acid after $2 \mathrm{~min}$. The absorbance of the reaction mixture was immediately read at $340 \mathrm{~nm}$ against a blank containing $2 \mathrm{~mL}$ of PBS, $0.1 \mathrm{~mL}$ of KI, and $0.2 \mathrm{~mL}$ of acetic acid. The chloramine-T absorbance at $340 \mathrm{~nm}$ was found linear within the range of 0 to $100 \mathrm{nmol} / \mathrm{mL}$, APOP concentrations were expressed as $\mathrm{nmol} \cdot \mathrm{mL}^{-1}$ chloramine-T equivalents.

\section{Estimation of catalase (CAT) activity}

CAT activities were determined using previously described method $[24,25]$ with some modifications. The reaction solution of CAT activities contained: $2.5 \mathrm{ml}$ of $50 \mathrm{mmol}$ phosphate buffer (pH 5.0), $0.4 \mathrm{ml}$ of $5.9 \mathrm{mmol}$ $\mathrm{H}_{2} \mathrm{O}_{2}$ and $0.1 \mathrm{ml}$ enzyme extract. Changes in absorbance of the reaction solution at $240 \mathrm{~nm}$ were determined after one minute. One unit of CAT activity was defined as an absorbance change of 0.01 as units $/ \mathrm{min}$.

\section{Estimation of reduced glutathione (GSH)}

Reduced glutathione was estimated by the method of Jollow et al. [26]. The total volume of $3.0 \mathrm{ml}$ assay mixture composed of $0.1 \mathrm{ml}$ filtered aliquot, $2.7 \mathrm{ml}$ phosphate buffer (0.1 M, pH 7.4) and 0.2 ml DTNB (5,5-dithiobis-2nitrobenzoic acid), (100 mM). The yellow color of the mixture was developed, read immediately at $412 \mathrm{~nm}$ on a Smart SpecTM plus Spectrophotometer and expressed as $\mathrm{ng} / \mathrm{mg}$ protein.

\section{Histopathalogical assessments}

For microscopic evaluation liver tissues were fixed in neutral buffered formalin and embedded in paraffin, sectioned at $5 \mu \mathrm{m}$ and subsequently stained with hematoxylin/eosin to see the architecture of hepatic tissue and inflammatory cell infiltration. Sirious red staining for fibrosis and prussiun blue staining for iron deposition were also done in liver sections. Sections were then studied and photographed under light microscope (Zeiss Axioscope) at 40X magnifications.

\section{Statistical analysis}

All values are expressed as mean \pm standard error of mean (SEM). The results were evaluated by using the Two way or One-way ANOVA followed by Bonferroni test using Graph Pad Prism Software, version 6. Statistical significance was considered $p<0.05$ in all cases.

\section{Result}

Effect on body weight, food and water intake

Body weight of each rat was recorded every day during the experiment, and \% change was calculated for all groups. It was found that the body weights of rats were decreased in $\mathrm{CCl}_{4}$ treated rats compared to the control (Figure 1). However, ucche supplementation did not improve the weight reduction in $\mathrm{CCl}_{4}$ treated rats. Moreover, $\mathrm{CCl}_{4}$ intoxicated group significantly decreased food and water intake compare to control rats, reduction of food and water intake was further improved in ucche treated group (Figure 1).

\section{Effect on organ wet weight}

Table 1 shows the effect of various treatments on the rats' organs weight. The spleen wet weight was significantly $(\mathrm{p}<0.05)$ increased in the $\mathrm{CCl}_{4}$-treated rats compared to control group rats. Ucche (10\% per $\mathrm{kg}$ of diet) treatment was significantly $(\mathrm{p}<0.05)$ attenuated the wet weight gain of the spleen in the $\mathrm{CCl}_{4}$-treated rats. Moreover, $\mathrm{CCl}_{4}$-treated rats showed slight decrease in liver wet weight, however, ucche (10\% per $\mathrm{kg}$ of diet) treatment did not change the wet weight of the liver compared to the control (Table 1). Another crucial finding in this study was the reduction of kidney wet weight due to $\mathrm{CCl}_{4}$ intoxication. Apart from these findings, $\mathrm{CCl}_{4}$ intoxication increased the 


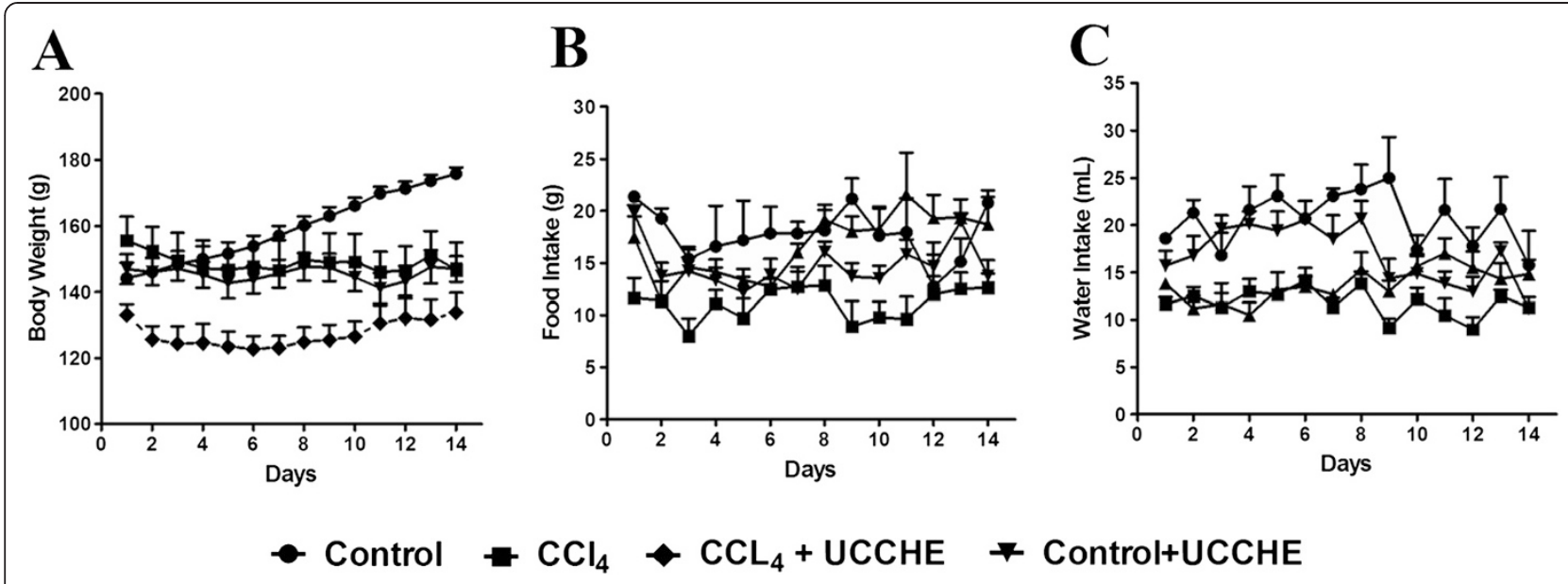

Figure 1 Effect of bitter melon (Ucche) on body weight (A), food intake (B) and water intake (C) in $\mathrm{CCl}_{4}$ treated rats.

heart wet weight in rats which was normalized due to ucche supplementation (Table 1).

Effect on biochemical parameter of liver functions Biochemical measurement of liver functions revealed that, $\mathrm{CCl}_{4}$ induced a significant increase in plasma AST, ALT, and ALP activity compared with control values, respectively (Table 2). Treatment of animals with ucche (10\% per $\mathrm{kg}$ of diet) concomitantly with $\mathrm{CCl}_{4}$ significantly counteracted the alteration in all hepatotoxicity indices compared to the $\mathrm{CCl}_{4}$-intoxicated group. In addition, treatment of animals with ucche alone for 2 weeks did not show any significant change in liver enzymes compared with the control group (Table 2).

\section{Oxidative stress markers and antioxidant enzymes}

To determine the oxidative stress in our study, we evaluated the MDA, nitric oxide and APOP content in plasma and liver homogenates. $\mathrm{CCl}_{4}$ induced rats showed a higher concentration of lipid peroxidation product MDA both in plasma and liver homogenates (Table 2) $(7.7 \pm 0.91$ and
$57.16 \pm 6.44 \mathrm{nmol} / \mathrm{mL}$ in plasma and liver homogenates respectively). Additionally, ucche (10\% per $\mathrm{kg}$ of diet) co-treatment significantly reduced the level of lipid peroxides compared to $\mathrm{CCl}_{4}$ intoxicated group (6.71 \pm 0.77 and $36.92 \pm 1.98 \mathrm{nmol} / \mathrm{mL}$ in plasma and liver homogenates respectively); however, lipid peroxide level was still higher than the control.

$\mathrm{CCl}_{4}$ have profound effect on APOP development in plasma and liver. $\mathrm{CCl}_{4}$ challenge significantly increased the APOP concentration in plasma and liver $(164.4 \pm 15.15$ and $1357.62 \pm 91.06 \mathrm{nmol} / \mathrm{mL}$ equivalent to Chloramine-T respectively) which was decreased due to ucche $(10 \%$ per $\mathrm{kg}$ of diet) supplementation in $\mathrm{CCl}_{4}$ intoxicated rats $(84.3 \pm 8.8$ and $977.50 \pm 63.05 \mathrm{nmol} / \mathrm{mL}$ equivalent to Chloramine- $\mathrm{T}$ respectively).

Nitric oxide measured as nitrate was also increased both in plasma and liver homogenates (5.8 \pm 0.3 and $35.62 \pm 4.21 \mathrm{nmol} / \mathrm{mL}$ in plasma and liver homogenates respectively) compared to control rats which was normalized by ramipril treatment in $\mathrm{CCl}_{4}$ intoxicated group (Table 2). $\mathrm{CCl}_{4}$ induced a significant decrease in liver

Table 1 Effect of bitter melon (Ucche) on body weight, food and water intake and organ weight of $\mathrm{CCl}_{4}$ treated rats

\begin{tabular}{|c|c|c|c|c|c|c|c|}
\hline \multirow[t]{2}{*}{ Parameters } & \multirow[t]{2}{*}{ Control } & \multirow[t]{2}{*}{ Control + Ucche } & \multirow[t]{2}{*}{$\mathrm{CCl}_{4}$} & \multirow[t]{2}{*}{$\mathrm{CCl}_{4}+$ Ucche } & \multicolumn{3}{|l|}{$p$ values } \\
\hline & & & & & $\overline{\mathrm{CCl}_{4}}$ & Treatment & Interaction \\
\hline Initial Body weight & $144.15 \pm 4.65$ & $146.93 \pm 4.51$ & $155.67 \pm 7.13$ & $133.14 \pm 3.19$ & 0.0752 & 0.8310 & 0.0261 \\
\hline Final Body weight & $175.83 \pm 1.90$ & $147.00 \pm 3.81$ & $146.68 \pm 8.33$ & $133.90 \pm 5.89$ & 0.0013 & 0.0012 & 0.1630 \\
\hline Food intake/d & $17.8 \pm 0.64$ & $14.75 \pm 0.60$ & $11.08 \pm 0.46$ & $16.74 \pm 0.81$ & 0.0013 & 0.0509 & $<0.0001$ \\
\hline Water intake/d & $20.58 \pm 0.77$ & $16.94 \pm 0.89$ & $11.80 \pm 0.41$ & $13.72 \pm 0.54$ & 0.7271 & 0.0722 & 0.7751 \\
\hline Liver wet weight & $6.09 \pm 0.36$ & $5.25 \pm 0.10$ & $5.62 \pm 0.25$ & $4.93 \pm 0.47$ & $<0.0001$ & 0.2282 & 0.0134 \\
\hline Kidney wet weight & $1.04 \pm 0.07$ & $0.95 \pm 0.03$ & $0.86 \pm 0.04$ & $0.71 \pm 0.19$ & 0.5910 & $<0.0001$ & 0.9141 \\
\hline Heart wet weight & $0.42 \pm 0.02$ & $0.46 \pm 0.01$ & $0.52 \pm 0.01$ & $0.45 \pm 0.05$ & 0.1995 & $<0.0001$ & 0.1995 \\
\hline Spleen wet weight & $0.49 \pm 0.06$ & $0.58 \pm 0.02$ & $0.81 \pm 0.09$ & $0.58 \pm 0.04$ & $<0.0001$ & 0.3009 & 0.0067 \\
\hline
\end{tabular}

Values are presented as mean \pm SEM. $\mathrm{N}=5-7$ in each group or otherwise specified. Two way or One way ANOVA with Bonferoni tests were done as post hoc test. Values are considered significance at $\mathrm{p}<0.05$. a vs $\mathrm{b}$, control vs $\mathrm{CCl}_{4} ; \mathrm{b}$ vs $\mathrm{c}, \mathrm{CCl}_{4}$ vs ucche treatment. 
Table 2 Effect of bitter melon (ucche) on biochemical parameter in plasma and liver

\begin{tabular}{|c|c|c|c|c|c|c|c|}
\hline \multirow[t]{2}{*}{ Parameters } & \multicolumn{4}{|l|}{ Groups } & \multicolumn{3}{|l|}{$p$ values } \\
\hline & Control & Control + Ucche & $\mathrm{CCl}_{4}$ & $\mathrm{CCl}_{4}+$ Ucche & $\mathrm{CCl}_{4}$ & Treatment & Interaction \\
\hline \multicolumn{8}{|l|}{ Plasma } \\
\hline AST(U/L) & $19.0 \pm 1.6$ & $21.32 \pm 1.68$ & $37.9 \pm 3.1$ & $23.3 \pm 4.0$ & 0.0374 & 0.0012 & 0.0062 \\
\hline$A L T(U / L)$ & $13.8 \pm 1.7$ & $16.59 \pm 2.62$ & $30.5 \pm 3.1$ & $18.7 \pm 1.9$ & 0.0831 & 0.0012 & 0.0082 \\
\hline$A L P(U / L)$ & $50.8 \pm 3.3$ & $50.92 \pm 2.76$ & $81.2 \pm 6.1$ & $63.9 \pm 4.7$ & 0.0731 & 0.0001 & 0.0690 \\
\hline $\mathrm{MDA}(\mathrm{nmol} / \mathrm{mL})$ & $6.34 \pm 0.37$ & $3.57 \pm 0.54$ & $7.7 \pm 0.91$ & $6.71 \pm 0.77$ & 0.0731 & 0.0001 & 0.0690 \\
\hline $\mathrm{NO}(\mathrm{nmol} / \mathrm{mL})$ & $3.22 \pm 0.27$ & $2.24 \pm 0.22$ & $5.8 \pm 0.3$ & $1.15 \pm 0.32$ & $<0.0001$ & 0.0195 & $<0.0001$ \\
\hline APOP $(\mathrm{nmol} / \mathrm{mL}$ equivalent to Chloramine-T) & $82.60 \pm 8.49$ & $67.0 \pm 9.2$ & $164.4 \pm 15.15$ & $84.3 \pm 8.8$ & 0.0340 & 0.0102 & 0.3072 \\
\hline Catalase (U/min) & $6.00 \pm 0.32$ & $4.28 \pm 0.38$ & $2.93 \pm 0.60$ & $5.07 \pm 0.74$ & 0.6960 & 0.0343 & 0.0011 \\
\hline GSH (ng/mg protein) & $20.05 \pm 1.81$ & $18.39 \pm 1.03$ & $12.72 \pm 0.57$ & $16.39 \pm 0.57$ & 0.3788 & 0.0005 & 0.0270 \\
\hline \multicolumn{8}{|l|}{ Liver } \\
\hline AST(U/L) & $36.18 \pm 3.22$ & $31.01 \pm 3.46$ & $65.18 \pm 3.87$ & $46.51 \pm 2.11$ & 0.0023 & $<0.0001$ & 0.0594 \\
\hline $\operatorname{ALT}(\mathrm{U} / \mathrm{L})$ & $26.00 \pm 3.88$ & $34.67 \pm 2.24$ & $77.61 \pm 4.80$ & $28.77 \pm 1.49$ & $<0.0001$ & $<0.0001$ & $<0.0001$ \\
\hline$A L P(U / L)$ & $30.33 \pm 3.67$ & $31.42 \pm 3.54$ & $113.53 \pm 3.71$ & $68.25 \pm 3.67$ & $<0.0001$ & $<0.0001$ & $<0.0001$ \\
\hline $\mathrm{NO}(\mathrm{nmol} / \mathrm{mL})$ & $15.87 \pm 1.56$ & $20.21 \pm 0.45$ & $35.62 \pm 4.21$ & $18.11 \pm 2.17$ & 0.0225 & 0.0036 & 0.0006 \\
\hline MDA $(\mathrm{nmol} / \mathrm{mL})$ & $21.85 \pm 1.86$ & $24.62 \pm 4.88$ & $57.16 \pm 6.44$ & $36.92 \pm 1.98$ & 0.0741 & $<0.0001$ & 0.0226 \\
\hline APOP $(\mathrm{nmol} / \mathrm{mL}$ equivalent to Chloramine-T) & $365.00 \pm 40.19$ & $450.0 \pm 75.83$ & $1357.62 \pm 91.06$ & $977.50 \pm 63.05$ & 0.0491 & $<0.0001$ & 0.0097 \\
\hline Catalase (U/min) & $52.13 \pm 4.02$ & $68.40 \pm 5.92$ & $26.32 \pm 3.82$ & $50.27 \pm 2.33$ & 0.0003 & $<0.0001$ & 0.3967 \\
\hline GSH (ng/mg protein) & $21.22 \pm 1.91$ & $19.22 \pm 1.13$ & $45.98 \pm 5.05$ & $32.89 \pm 1.79$ & 0.0171 & $<0.0001$ & 0.0703 \\
\hline
\end{tabular}

Values are presented as mean \pm SEM. $\mathrm{N}=5-6$ in each group or otherwise specified. Two way or One way ANOVA with Bonferoni tests were done as post hoc test. Values are considered significance at $\mathrm{p}<0.05$. a vs $\mathrm{b}$, control vs $\mathrm{CCl}_{4} ; \mathrm{b}$ vs $\mathrm{c}, \mathrm{CCl}_{4}$ vs ucche treatment. APOP-Advanced protein oxidation product, expressed as $\mathrm{nmol} / \mathrm{mL}$ equivalent to Chloramine-T.

antioxidant enzyme activities GSH and CAT respectively, compared to the control levels. In addition, $\mathrm{CCl}_{4}$ induced a significant increase in lipid peroxide level by more than four folds compared with the control group (Table 2). Treatment of animals with ucche $(10 \%$ per $\mathrm{kg}$ of diet) concomitantly to $\mathrm{CCl}_{4}$ significantly counteracted the oxidative stress effect of $\mathrm{CCl}_{4}$. It was found that, the level of GSH and CAT activity restored near normal compared to $\mathrm{CCl}_{4}$ intoxicated group (Table 2).

\section{Inflammation, fibrosis iron deposition in liver}

Inflammation was seen in rats treated with $\mathrm{CCl}_{4}$. Massive serge of inflammatory cells was found in the centilobular part of liver section stained with $\mathrm{H} \& \mathrm{E}$ staining in $\mathrm{CCl}_{4}$ treated rats group (Figure 2C). Necrotized tissue scar and ballooning of the hepatocytes were also seen in liver of $\mathrm{CCl}_{4}$ treated rats. ucche (10\% per kg of diet) co-treatment attenuated the inflammatory cell infiltration and necrosis in the liver tissues of $\mathrm{CCl}_{4}$ treated rats (Figure 2D). Liver fibrosis was evaluated by histologically by visualizing the red color of collagen fibers using Sirius red stain. In contrast, the collagen fibers were heavily deposited around portal tracts and central veins in $\mathrm{CCl}_{4}$-intoxicated group and extended from central vein to portal tract resulting in the formation of pseudolobules (Figure 2G). Histological staining also revealed massive iron deposition in liver section stained for free iron depot in $\mathrm{CCl}_{4}$ treated rats (Figure 3C). Ucche supplementation decreased this iron deposition in $\mathrm{CCl}_{4}$ treated rats (Figure 3D).

\section{Discussion}

Liver is one of the vital organs in our body responsible for detoxification of toxic chemicals and drugs. Chronic liver diseases are increasing in recent years and the medical treatments for these diseases are usually difficult to handle and showed limited efficacy. Therefore, it is necessary to find new alternative treatment for the management of liver diseases. $\mathrm{CCl}_{4}$ treatment is one of the most used methods for the study of experimental hepatic dysfunction nowadays; however, $\mathrm{CCl}_{4}$ is considered as an extremely toxic chemical agent [27]. Several important basic mechanisms involving of tissue damages induced by $\mathrm{CCl}_{4}$ have been proposed, such as reactive free radical metabolites, lipid peroxidation, metabolic activation, covalent binding and disturbance of calcium homeostasis [3]. The present study demonstrates that fresh ucche supplementation prevented oxidative stress, lowered inflammatory cell infiltration and fibrosis in liver and improved the hepatic enzymes function against $\mathrm{CCl}_{4}$-induced liver injury in rats.

Oxidative stress is the major cause of tissue damage in $\mathrm{CCl}_{4}$ treated animal model of hepatic dysfunction. $\mathrm{CCl}_{4}$ 


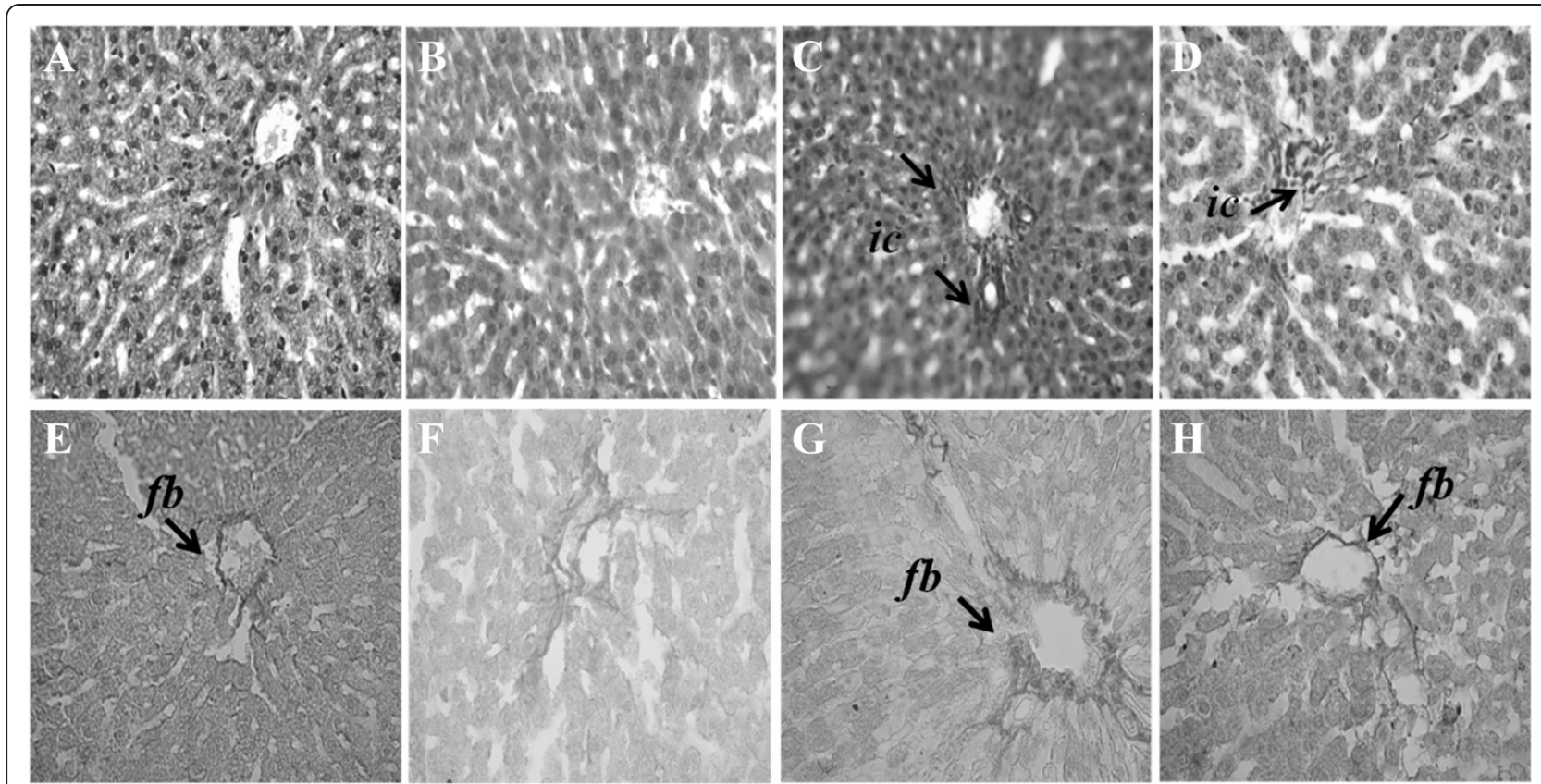

Figure 2 Effect of bitter melon (Ucche) on hepatic inflammation and fibrosis in $\mathrm{CCl}_{4}$ treated rats. A, E- Control; $\mathbf{B}, \mathbf{F}-\mathrm{Control}_{+} \mathrm{Ucche}$; C, G- $\mathrm{CCl}_{4}$ and $\mathbf{D}, \mathbf{H}-\mathrm{CCl}_{4}+$ Ucche. Magnification 40x. ic-inflammatory cells; fb- fibrosis.

is metabolized by liver cytochrome $\mathrm{P} 450$ and converted into the free radical ${ }^{\circ} \mathrm{CCl}_{3}[28,29]$. The free radical attacks hepatocytes and causes necrosis of parenchymal cells. We found that the concentration of MDA and APOP, which are indices of oxidative stress, were elevated in $\mathrm{CCl}_{4}$-challenged rats. However, decreased concentrations of these two compounds were found in plasma and the liver tissues of those $\mathrm{CCl}_{4}$-rats that were treated with ucche supplementation, which suggests that fresh ucche can effectively protect against lipid peroxidation and protein oxidation. Similar results were also reported by other investigators that fruit extract $(300 \mathrm{mg} / \mathrm{kg})$ and the plant extract at a dose of $5 \mathrm{ml} / \mathrm{kg}$ also produced significant protection of liver damage by preventing elevated TBARS and hydroperoxides concentration and increased the levels of glutathione peroxidase (GPx), superoxide dismutase (SOD), catalase and reduced glutathione in ammonium chloride-induced toxicity in rats $[13,30]$. Catalase is an important antioxidant enzymes responsible for the scavenging of free radical generated in tissue. Catalase enzyme exists in all aerobic cells, is a hemeprotein that metabolizes the $\mathrm{H}_{2} \mathrm{O}_{2}$ to form oxygen and water. Szymonik-Lesiuk et al. reported that $\mathrm{CCl}_{4}$ intoxication leads to changes in antioxidant enzymes activity [31]. In our study, $\mathrm{CCl}_{4}$ treatment causes breakdown of catalase mediated prevention of tissue damage and lowered the catalase activity which was further improved to near normal by ucche supplementation. Oxidative stress mediated tissue damage also increases the liver marker enzyme activities. Damage to the liver typically results in leakage of AST and ALT into the bloodstream [32]. In the present study $\mathrm{CCl}_{4}$ administration to rats caused a

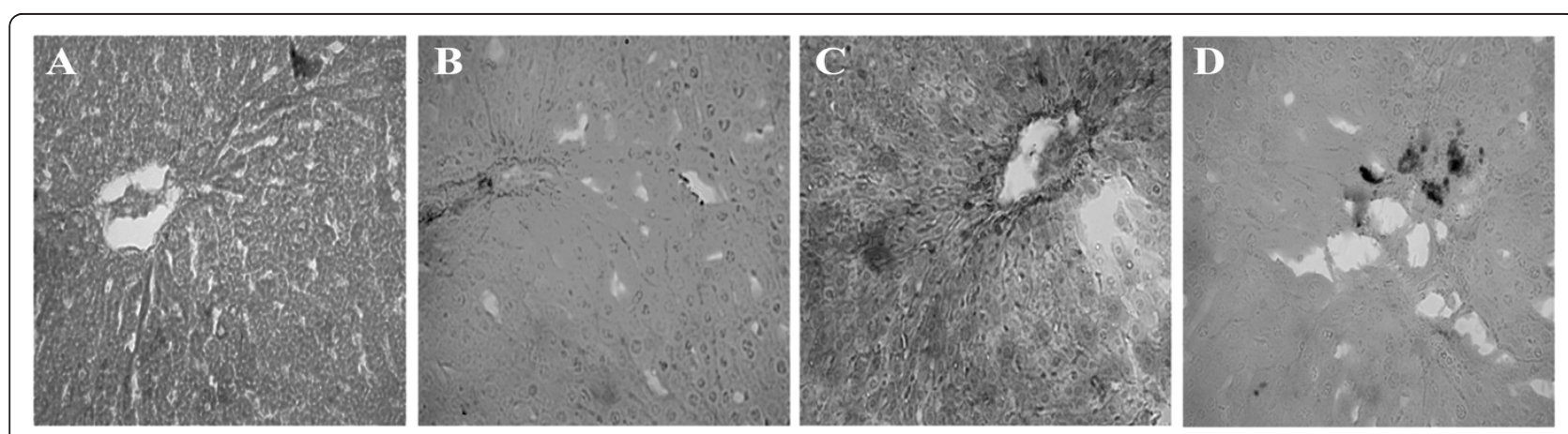

Figure 3 Effect of ucche on hepatic iron deposition in $\mathrm{CCl}_{4}$ treated rats. A- Control; $\mathbf{B}$ - Control $+\mathrm{Ucche}$; $\mathbf{C}-\mathrm{CCl}_{4}$ and $\mathbf{D}-\mathrm{CCl}_{4}+\mathrm{Ucche}$. Blue dots- iron pigment, Magnification 40x. 
significant increase in serum AST, ALT and ALP activity which were further normalized by ucche supplementation. Nitric oxide is another mediator of oxidative stress despite of its valuable role in the maintenance of vascular tone and as signaling molecule. However, excess production of nitric oxide by iNOS may lead to hepatic injury which can be reversed by scavenging of nitric oxide $[33,34]$. Ucche supplementation also reduces the elevated nitrate concentration in plasma and tissues of $\mathrm{CCl}_{4}$ treated rats. Our results are also comparable to Chaudhari et al. who reported that hydroalcoholic extract of the plant leaves $(100$ and $200 \mathrm{mg} / \mathrm{kg}$ ) normalized the levels of SGOT, SGPT, ALP, total bilirubin and prevented steatosis, centrilobular necrosis and vacuolization in liver of carbon tetrachloride induced liver damage in rats [35]. Similar findings were also reported in another study that investigated the hepatoprotective effects of plant bioactive compounds against $\mathrm{CCl}_{4}$-induced injury in rats hepatocytes [36].

Moreover, oxidative stress mediated tissue damage may trigger inflammation and fibrosis in liver of $\mathrm{CCl}_{4}$ treated rats. Liver fibrosis is also characterized by a distortion of liver tissue architecture and an excessive deposition of extra cellular matrix (ECM) proteins that type I collagen predominates [7]. Hepatic stellate cells (HSCs) have been recognized as the main matrixproducing cells in the process of liver fibrosis. Kupffer cells (KCs) could activate HSCs by producing and releasing a variety of mediators, such as proinflammatory cytokines and reactive oxygen species that fulfill a crucial function in the inflammatory responses of the liver [37]. Histological examination also demonstrated that a large number of inflammatory cells infiltrated into the intralobular and interlobular regions together with increased collagen fibers in $\mathrm{CCl}_{4}$ treated rats compared with normal rats. On the contrary, ucche supplementation remarkably reduced the immigration of inflammatory cells and the deposition of collagen fibers compared with rats in model group treated with $\mathrm{CCl}_{4}$.

Another key finding in our model is the deposition of iron in hepatic tissues assessed through histologically by iron staining. Iron deposition is characteristics of many forms of liver diseases including viral hepatitis-C, alcoholic and nonalcoholic hepatitis [38,39]. In hepatic diseases, the Kupffer cells $(\mathrm{KC})$ and liver cells are not capable of processing the iron due to heam oxygenase deficiency and deposited in the tissue which further contributes to oxidative tissue damage by fenton reaction [40-42]. Previous authors also reported that iron overload can enhance the development of liver cirrhosis in animal models $[43,44]$. Clinical evidence also noted that iron-loaded livers of hemochromatosis patients were also found to exhibit oxidative stress and enhanced expression of TGF- $\beta 1$ [45]. TGF- $\beta 1$ is the key regulatory growth factor secreted by fibroblast cells due to activation by inflammatory stimuli and oxidative stress [46]. Thus, the deposited iron can also accelerate the advancement of liver fibrosis by increasing $\alpha 1$-(I)-collagen mRNA expression [47]. In our study, ucche supplementation significantly reduced the iron deposition and fibrosis in liver of rats treated with $\mathrm{CCl}_{4}$ further confirmed the reduction of oxidative stress in liver.

Phenolic or polyphenolic compounds are potent antioxidants and are capable of preventing oxidative stress in various diseases including liver damage [48]. Previous reports suggest that various phenolic compounds such as gallic acid, tannic acid, (+)-catechin, caffeic acid, $p$-coumaric, gentisic acid, chlorogenic acid, and epicatechin are present in Momordica charantia plants $[14,15]$. Our analysis (unpublished data) on ucche fruit extract showed that ellagic acid and myricetin are present in abundant amount. Ellagic acid showed preventive effect in isoniazid-rifampicin induced liver damage [49] and cisplatin-induced oxidative stress in liver [50]. Myricetin are also effective in lowering plasma lipids (which is one of the mechanism of hepatic protection in non alcoholic fatty liver like diseases), in high fat diet fed animals [51]. However, it is not possible to speculate which phenolic compound responsible for the preventive activity in liver showed by ucche supplementation in this study, probably a combined effects of all phenolic compounds play their role and gave a synergistic effect.

\section{Conclusions}

In conclusion, our findings revealed that ucche supplementation has a protective effect against $\mathrm{CCl}_{4}$ induced hepatotoxicity. The hepatoprotective effects of ucche supplementation are likely related to the prevention of oxidative stress by increasing antioxidant activity, lowering lipid peroxidation, and improving the function of liver cells. Moreover, ucche supplementation also promotes hepatic protection by decreasing inflammation and fibrosis probably mediated by inhibiting iron mediated signaling pathways and HSCs activation. Further studies are needed to investigate the molecular mechanism of the hepatoprotective effect of ucche supplementation in $\mathrm{CCl}_{4}$ treated rats.

\section{Competing interests}

The authors declare that they have no competing interests.

\section{Authors' contributions}

MATS and MRHC carried out the experiment and animal take care, participated in the biochemical analysis and drafted the manuscript. NT carried out the biochemical analysis. HH Participated in the statistical analysis and drafted the manuscript. MMR participated in the design of the study and performed the statistical analysis. MAA conceived of the study, and participated in its design, histological analysis, statistical analysis and coordination. MAA also supervised and trained MATS, MRHC and NT for all laboratory procedures required for this research. All authors read and approved the final manuscript. 


\section{Acknowledgements}

Authors gratefully acknowledge the logistic support provided by Department of Pharmaceutical Sciences, North South University Bangladesh.

\section{Author details}

'Department of Pharmaceutical Sciences, North South University, Dhaka, Bangladesh. ${ }^{2}$ BCSIR Laboratories, Bangladesh Council of Scientific and Industrial Research (BCSIR), Dhaka, Bangladesh.

\section{Received: 3 November 2014 Accepted: 26 March 2015}

\section{Published online: 11 April 2015}

\section{References}

1. Lee WM. Drug-induced hepatotoxicity. N Engl J Med. 2003;349(5):474-85

2. Weber LWD, Boll M, Stampfl A. Hepatotoxicity and mechanism of action of haloalkanes: carbon tetrachloride as a toxicological model. Crit Rev Toxicol. 2003:33(2):105-36.

3. Zhu W, Fung PC. The roles played by crucial free radicals like lipid free radicals, nitric oxide, and enzymes NOS and NADPH in $\mathrm{CCl}_{4}$-induced acute liver injury of mice. Free Radic Biol Med. 2000;29(9):870-80.

4. He SX, Luo JY, Wang YP, Wang YL, Fu H, Xu JL, et al. Effects of extract from Ginkgo biloba on carbon tetrachloride-induced liver injury in rats. World J Gastroenterol. 2006;12(24):3924-8.

5. Singh N, Kamath V, Narasimhamurthy K, Rajini PS. Protective effect of potato peel extract against carbon tetrachloride-induced liver injury in rats. Environ Toxicol Pharmacol. 2008;26(2):241-6.

6. Ai G, Liu Q, Hua W, Huang Z, Wang D. Hepatoprotective evaluation of the total flavonoids extracted from flowers of Abelmoschus manihot (L.) Medic: in vitro and in vivo studies. J Ethnopharmacol. 2013;146(3):794-802.

7. Cohen-Naftaly M, Friedman SL. Current status of novel antifibrotic therapies in patients with chronic liver disease. Therap Adv Gastroenterol. 2011;4(6):391-417.

8. Reichenbach V, Ros J, FernÃ indez-Varo G, Casals G, Melgar-Lesmes P, Campos $\mathrm{T}$, et al. Prevention of fibrosis progression in $\mathrm{CCl}_{4}$-treated rats: role of the hepatic endocannabinoid and apelin systems. J Pharmacol Exp Ther. 2011;340(3):629-37.

9. Krawinkel MB, Keding GB. Bitter gourd (Momordica charantia): a dietary approach to hyperglycemia. Nutri Rev. 2006;64(7):331-7.

10. Shih C-C, Lin C-H, Lin W-L, Wu J-B. Momordica charantia extract on insulin resistance and the skeletal muscle GLUT 4 protein in fructose-fed rats. J Ethnopharmacol. 2009;123(1):82-90.

11. Matsui S, Yamane T, Takita T, Oishi Y, Kobayashi-Hattori K. The hypocholesterolemic activity of Momordica charantia fruit is mediated by the altered cholesterol- and bile acid-regulating gene expression in rat liver. Nutri Res. 2013;33:580-5.

12. Shih C-C, Shlau M-T, Lin C-H, Wu J-B. Momordica charantia ameliorates insulin resistance and dyslipidemia with altered hepatic glucose production and fatty acid synthesis and AMPK phosphorylation in high-fat-fed mice. Phytother Res. 2014;28(3):363-71.

13. Thenmozhi AJ, Subramanian P. Antioxidant potential of Momordica Charantia in ammonium chloride-induced hyperammonemic rats. Evidence-Based Complement Alternat Med. 2011, Article ID 612023.

14. Kubola J, Siriamornpun S. Phenolic contents and antioxidant activities of bitter gourd (Momordica charantia L.) leaf, stem and fruit fraction extracts in vitro. Food Chem. 2008;110(4):881-90.

15. Horax R, Hettiarachchy N, Islam S. Total phenolic contents and phenolic acid constituents in 4 varieties of bitter melons (Momordica charantia) and antioxidant activities of their extracts. J Food Sci. 2005;70(4):C275-80.

16. Horax R, Hettiarachchy N, Chen P. Extraction, quantification, and antioxidant activities of phenolics from pericarp and seeds of bitter melons (Momordica charantia) harvested at three maturity stages (immature, mature, and ripe). J Agric Food Chem. 2010;58(7):4428-33

17. Nakamura S, Murakami T, Nakamura J, Kobayashi H, Matsuda H, Yoshikawa M. Structures of new cucurbitane-type triterpenes and glycosides, karavilagenins and karavilosides, from the dried fruit of Momordica charantia L. in Sri Lanka. Chem Pharm Bull. 2006;54(11):1545-50.

18. Alam MA, Uddin R, Subhan N, Rahman MM, Jain P, Reza HM. Beneficial role of bitter melon supplementation in obesity and related complications in metabolic syndrome. J Lipids. 2015, Article ID 496169.

19. Wu S-J, Ng L-T. Antioxidant and free radical scavenging activities of wild bitte melon (Momordica charantia Linn. var. abbreviata Ser.) in Taiwan. LWT - Food Sci Technol. 2008;41(2):323-30
20. Niehaus WG, Samuelsson B. Formation of malonaldehyde from phospholipid arachidonate during microsomal lipid peroxidation. Eur J Biochem. 1968;6(1):126-30.

21. Tracey WR, Tse J, Carter G. Lipopolysaccharide-induced changes in plasma nitrite and nitrate concentrations in rats and mice: pharmacological evaluation of nitric oxide synthase inhibitors. J Pharmacol Exp Ther. 1995;272(3):1011-5.

22. Witko-Sarsat V, Friedlander M, Capeillère-Blandin C, Nguyen-Khoa T, Nguyen A, Zingraff J, et al. Advanced oxidation protein products as a novel marker of oxidative stress in uremia. Kidney Int. 1996;49:1304-13.

23. Tiwari BK, Kumar D, Abidi AB, Rizvi Sl. Efficacy of composite extract from leaves and fruits of medicinal plants used in traditional diabetic therapy against oxidative stress in alloxan-induced diabetic rats. ISRN Pharmacol 2014 Article ID 608590.

24. Khan R. Protective effects of Sonchus asper (L.) Hill, (Asteraceae) against $\mathrm{CCl}_{4}$-induced oxidative stress in the thyroid tissue of rats. BMC Complement Alternat Med. 2012;12(1):181

25. Chance B, Maehly AC. Assay of catalase and peroxidases. Methods Enzymol. 1955;11:764

26. Jollow D, Mitchell J, Zampaglione N, Gillette J. Bromobenzene-induced liver necrosis: protective role of glutathione and evidence for 3,4-bromobenzene oxide as the hepatotoxic metabolite. Pharmacol. 1974;11:151-69.

27. Pierce RA, Glaug MR, Greco RS, Mackenzie JW, Boyd CD, Deak SB. Increased procollagen mRNA levels in carbon tetrachloride-induced liver fibrosis in rats. J Biol Chem. 1987;262(4):1652-8.

28. Khan $\mathrm{R}$, Khan M, Sahreen S. CCl 4 -induced hepatotoxicity: protective effect of rutin on p53, CYP2E1 and the antioxidative status in rat. BMC Complement Alternat Med. 2012;12:178.

29. Fu Y, Zheng S, Lin J, Ryerse J, Chen A. Curcumin protects the rat liver from $\mathrm{CCl}_{4}$-caused injury and fibrogenesis by attenuating oxidative stress and suppressing inflammation. Mol Pharmacol. 2008;73(2):399-409.

30. Ching RHH, Yeung LOY, Tse IMY, Sit W-H, Li ETS. Supplementation of bitter melon to rats fed a high-fructose diet during gestation and lactation ameliorates fructose-induced dyslipidemia and hepatic oxidative stress in male offspring. J Nutri. 2011;141(9):1664-72.

31. Szymonik-Lesiuk S, Czechowska G, Stryjecka-Zimmer M, Słomka M, Madro A, Celiński K, et al. Catalase, superoxide dismutase, and glutathione peroxidase activities in various rat tissues after carbon tetrachloride intoxication. J Hepatobiliary Pancreat Surg. 2003;10(4):309-15.

32. Bolanle JD, Adetoro KO, Balarabe SA, Adeyemi OO. Hepatocurative potential of Vitex doniana root bark, stem bark and leaves extracts against $\mathrm{CCl}_{4}$-induced liver damage in rats. Asian Pac J Trop Biomed. 2014;4(6):480-5.

33. Quan J, Piao L, Wang X, Li T, Yin X. Rossicaside B protects against carbon tetrachloride-induced hepatotoxicity in mice. Basic Clin Pharmacol Toxicol. 2009;105(6):380-6.

34. Nadler EP, Dickinson EC, Beer-Stolz D, Alber SM, Watkins SC, Pratt DW, et al. Scavenging nitric oxide reduces hepatocellular injury after endotoxin challenge. Am J Physiol Gastrointest Liver Physiol. 2001;281(1):G173-81.

35. Chaudhari B, Chaware V, Joshi Y, Biyani K. Hepatoprotective activity of hydroalcoholic extract of Momordica charantia Linn. leaves against carbon tetra chloride induced hepatopathy in rats. Int J ChemTech Res. 2009;1:355-8.

36. El-Halawany AM, Dine RSE, El Sayed NS, Hattori M. Protective effect of Aframomum melegueta phenolics against $\mathrm{CCl}_{4}$-induced rat hepatocytes damage; role of Apoptosis and pro-inflammatory cytokines inhibition. Sci Rep. 2014;4:Article number: 5880.

37. Liu C, Tao Q, Sun M, Wu JZ, Yang W, Jian P, et al. Kupffer cells are associated with apoptosis, inflammation and fibrotic effects in hepatic fibrosis in rats. Lab Invest. 2010;90(12):1805-16.

38. Tung BY, Emond MJ, Bronner MP, Raaka SD, Cotler SJ, Kowdley KV. Hepatitis $C$, iron status, and disease severity: relationship with HFE mutations. Gastroenterol. 2003;124(2):318-26.

39. Purohit V, Russo D, Salin M. Role of iron in alcoholic liver disease: introduction and summary of the symposium. Alcohol. 2003;30(2):93-7.

40. Richards JA, Wigmore SJ, Devey LR. Heme oxygenase system in hepatic ischemia-reperfusion injury. World J Gastroenterol. 2010;16(48):6068-78.

41. Immenschuh S, Baumgart-Vogt E, Mueller S. Heme oxygenase-1 and iron in liver inflammation: a complex alliance. Curr Drug Targets. 2010;11(12):1541-50.

42. Abraham NG, Kappas A. Pharmacological and clinical aspects of heme oxygenase. Pharmacol Rev. 2008;60(1):79-127.

43. He JY, Ge WH, Chen Y. Iron deposition and fat accumulation in dimethylnitrosamine-induced liver fibrosis in rat. World J Gastroenterol. 2007;13(14):2061-5. 
44. Arezzini B, Lunghi B, Lungarella G, Gardi C. Iron overload enhances the development of experimental liver cirrhosis in mice. Int J Biochem Cell Biol. 2003;35(4):486-95.

45. Houglum K, Ramm GA, Crawford DH, Witztum JL, Powell LW, Chojkier M. Excess iron induces hepatic oxidative stress and transforming growth factor beta1 in genetic hemochromatosis. Hepatol. 1997;26(3):605-10.

46. De Minicis S, Marzioni M, Saccomanno S, Rychlicki C, Agostinelli L, Trozzi L, et al. Cellular and molecular mechanisms of hepatic fibrogenesis leading to liver cancer. Transl Gastrointest Cancer. 2011;1(1):88-94.

47. Pietrangelo AGR, Casalgrandi G, Geerts A, De Bleser P, Montosi G, Ventura E. Enhanced hepatic collagen type I mRNA expression into fat-storing cells in a rodent model of hemochromatosis. Hepatol. 1994;19(3):714-21.

48. Lee C-C, Shen S-R, Lai Y-J, Wu S-C. Rutin and quercetin, bioactive compounds from tartary buckwheat, prevent liver inflammatory injury. Food \& Function. 2013;4(5):794-802.

49. Ambrose SS, Solairaj P, Subramoniam A. Effectiveness of ellagic acid on isoniazid-rifampicin induced liver damage in rats. J Pharmacol Pharmacother. 2013:4(1):60-2

50. Girish C, Pradhan SC. Drug development for liver diseases: focus on picroliv, ellagic acid and curcumin. Fund Clin Pharmacol. 2008;22(6):623-32.

51. Chang CJ, Tzeng T-F, Liou S-S, Chang Y-S, Liu I-M. Myricetin increases hepatic peroxisome proliferator-activated receptor-a, protein expression and decreases plasma lipids and adiposity in rats. Evid Based Complementary Altern Med. 2012 Article ID 787152.

\section{Submit your next manuscript to BioMed Central and take full advantage of:}

- Convenient online submission

- Thorough peer review

- No space constraints or color figure charges

- Immediate publication on acceptance

- Inclusion in PubMed, CAS, Scopus and Google Scholar

- Research which is freely available for redistribution 